Cahiers $d u$ MONDE RUSSE

\section{Cahiers du monde russe}

Russie - Empire russe - Union soviétique et États indépendants

49/2-3 | 2008

Sortie de guerre

\title{
The early stages of "legal purges" in Soviet Russia (1941-1945)
}

\section{Sergey Kudryashov et Vanessa Voisin}

\section{OpenEdition}

\section{Journals}

Édition électronique

URL : https://journals.openedition.org/monderusse/9129

DOI : 10.4000/monderusse. 9129

ISSN : $1777-5388$

\section{Éditeur}

Éditions de l'EHESS

\section{Édition imprimée}

Date de publication : 20 septembre 2008

Pagination : 263-296

ISBN : 978-2-7132-2196-5

ISSN : $1252-6576$

Référence électronique

Sergey Kudryashov et Vanessa Voisin, "The early stages of "legal purges" in Soviet Russia (1941-1945) », Cahiers du monde russe [En ligne], 49/2-3 | 2008, mis en ligne le 01 janvier 2011, consulté le 02 septembre 2022. URL : http://journals.openedition.org/monderusse/9129; DOI : https://doi.org/10.4000/monderusse.9129 
chercher : repérer : avancer

Cet article est disponible en ligne à l'adresse :

http://www.cairn.info/article.php?ID REVUE=CMR\&ID NUMPUBLIE=CMR 49\&ID ARTICLE=CMR 4920263

The early stages of "legal purges" in Soviet Russia (1941-1945)

par Sergey KUDRYASHOV et Vanessa VOISIN

\section{Editions de l'EHESS | Cahiers du monde russe}

2008/2-3 - Vol 49

ISSN 1252-6576 | ISBN 9782713221965 | pages 263 à 296

Pour citer cet article:

-Kudryashov S. et Voisin V., The early stages of "legal purges" in Soviet Russia (1941-1945), Cahiers du monde russe 2008/ 2-3, Vol 49, p. 263-296.

Distribution électronique Cairn pour les Editions de l'EHESS.

(C) Editions de l'EHESS. Tous droits réservés pour tous pays.

La reproduction ou représentation de cet article, notamment par photocopie, n'est autorisée que dans les limites des conditions générales d'utilisation du site ou, le cas échéant, des conditions générales de la licence souscrite par votre établissement. Toute autre reproduction ou représentation, en tout ou partie, sous quelque forme et de quelque manière que ce soit, est interdite sauf accord préalable et écrit de l'éditeur, en dehors des cas prévus par la législation en vigueur en France. Il est précisé que son stockage dans une base de données est également interdit. 


\section{THE EARLY STAGES OF "LEGAL PURGES" IN SOVIET RUSSIA (1941-1945)}

Throughout the European countries occupied by Axis troops during World War II, the liberation by Allied troops - supported by internal resistance generated a deep determination to sanction collaborators. The urge to administer the right punishment, and often, revenge, could be felt at the higher levels of political direction, as well as amidst the greatest part of the population, which experienced the harshness of Nazi occupation. ${ }^{1}$ In Belgium, France, the Czech provinces, Greece, the number of spontaneous beatings or murders of alleged collaborators mounted into the thousands (France). Popular anger - usually orchestrated by local fighters - was even staged or expressed in archaic rituals of public humiliation of yesterday's tormentors. ${ }^{2}$ The new powers organized large-scale systems of prosecution and administrative purges. Never before did contemporary Europe see a political purge reach such a scale. In spite of national

1. For France, see Association française pour l'histoire de la justice, La justice de l'épuration à la fin de la Seconde Guerre mondiale (P.: La Découverte, 2008); Philippe Buton, La joie douloureuse de la Libération de la France (Bruxelles: Éditions Complexe, IHTP-CNRS, 2004); Henri Lottman, Histoire de l'épuration, 1943-1953 (P.: Le Livre de Poche, 1994, first published 1986); Peter Novick, L'Épuration française, 1944-1949 (P.: Editions Balland, 1985, first published 1968); for Belgium, see Luc Huyse, Steven Dhondt, La répression des collaborations, 1942-1952 (Bruxelles: CRISP, 1993); for Czech provinces, see Benjamin Frommer, National Cleansing: Retribution against Nazi Collaborators in postwar Czechoslovakia (Cambridge/New York: Cambridge University Press, 2005); for Greece, see Mark Mazower, ed., After the War was Over: Reconstructing the Family, Nation, and State in Greece, 1943-1960 (Princeton/Oxford: Princeton University Press, 2000); for a European overview, see Istvan Deak, Jan Tomasz Gross, Tony Judt, eds., The Politics of Retribution in Europe: World War II and its Aftermath (Princeton: Princeton University press, 2000).

2. See Luc Capdevila, Les Bretons au lendemain de l'Occupation: imaginaire et comportement d'une sortie de guerre (Rennes: Presses universitaires de Rennes, 1999, chapters 7-10); JeanPierre Koscielniak, Collaboration et épuration en Lot-et-Garonne, 1940-1945 (Narrosse: Éditions d'Albret, 2003, 214-230); Fabrice Virgili, La France "virile": Des femmes tondues à la Libération (P.: Payot, 2000); Martin Conway, "Justice in Postwar Belgium: Popular Passions and Political Passions," Cahiers d'Histoire du temps présent, 2 (1997): 7-34. 
specificities, ${ }^{3}$ common features can be identified everywhere. For all its actors, retribution was the sine qua non condition to rebuild the country on a sound basis. Law and order had to be restored in the aftermath of arbitrary Nazi rule. The political leadership had to be purged of treacherous elements. The suffering caused by occupation had to be compensated for by punishing those who profited from the situation. Lastly, the restoration of national unity demanded that some of the collaborators be ostensibly excluded from the liberated community, allowing the majority of "wait-and-see" people to find their place in the victorious nation.

The USSR does not differ much from this general picture. Nevertheless, three major facts make its treatment of collaborators quite specific. First, political and social purges had been going on intensely during the previous decades. Prewar Soviet society was deeply shaken. It had just gone out of a huge process of "social engineering": in 1934 Stalin asserted that by then, enemy classes had been tamed or even exterminated and there were just two classes left in the Soviet Union - the working class and the peasantry, with the intelligentsia being a stratum. Then, in the late 1930s, new waves of repression redefined the political body and established complex relationships between central authority and intermediary ones, including Stalin's closest followers. ${ }^{4}$

As concerns the juridical aspect, political justice had been fostered since 1917 and could already boast a solid experience. ${ }^{5}$ Furthermore, the enemy was a most evil one, who had attacked without any legal declaration and despite the 1939 pact. ${ }^{6}$ In this context, acts of collaboration logically slotted in an already existing set of

3. Such as the choice of the governments at the eve of the invasion, the nature of the occupying forces' policies in each country, and wider reasons such as the internal situation of the country before the war.

4. The bibliography on the topic is vast. For a study of the highest powers, see Oleg Khlevniuk, Politbiuro: Mekhanizmy politicheskoi vlasti v 1930-e gody [Politbiuro: Political power mechanism in the 1930s] (M.: ROSSPEN, 1996); for insights in police practices, La police politique en Union soviétique, 1918-1953, Cahiers du monde russe, 42, 2-4 (2002); Studies about the terror: Arch Getty, Oleg V. Naumov, The Road to Terror: Stalin and the Self-Destruction of the Bolsheviks, 1932-1939 (New Haven/London: Yale University Press, 1999); Barry McLoughlin, Kevin McDermott, eds., Stalin's Terror: High Politics and mass Repression in the Soviet Union (Houndmills/New York: Palgrave Macmillan, 2004); Gábor Rittersporn, Simplifications staliniennes et complications soviétiques: Tensions sociales et conflits politiques en URSS, 1933-1953 (P.: Editions des Archives contemporaines, 1991); Robert W. Thurston, Life and Terror in Stalin's Russia, 1934-1941 (New Haven/London: Yale University Press, 1996); Aleksandr Iu. Vatlin, Terror raionnogo masshtaba: "massovye operatsii" NKVD v Kuntsevskom raione Moskovskoi oblasti 1937-1938 gg. [Terror of the local scale: "mass NKVD operations" in Kuznetsk district of the Moscow region, 1937-1938] (M.: ROSSPEN, 2004); Nicolas Werth, La terreur et le désarroi : Staline et son système (P.: Perrin, 2007).

5. Vladimir N. Kudriavtsev, Aleksei I. Trusov, Politicheskaia iustitsiia V SSSR [Political justice in USSR] (SPb.: Iuridicheskii Tsentr Press, Nauka, 2002). For excellent regional overviews, see Hiroaki Kuromiya, Freedom and Terror in the Donbass: A Ukrainian-Russian Borderland 1870s-1990s (Cambridge: Cambridge University Press, 1998) and James Harris, The Great Urals: Regionalism and the Evolution of the Soviet System (Ithaca/London: Cornell University Press, 1999).

6. In this way, Nazi Germany broke international law in two respects: by perpetrating evil acts, and by ignoring the duty of any "civilized" country to officially declare war (The Hague Conventions, 1899 and 1907). 
representations - a manicheist system opposing loyal supporters of the Revolution to malevolent opponents, the so-called "counterrevolutionary elements." Moreover, it fitted perfectly in the judicial scheme of a counterrevolutionary plot assisted by foreign enemies of the Soviet state. Well-publicized illustrations of that were the recently held second and first Moscow trials, ${ }^{7}$ and older repressions against internal wreckers, terrorists, spies (see, for example, the repression following the Shakhty trial in 1928-1930). Consequently, the nature and meaning of collaboration do not seem to have generated much debate and reflection. It was a political crime which deserved the harshest retribution. In practice however, hints of attempts at nuancing that idea can be found.

Furthermore, in Soviet Russia, the punishment of collaborators took place in the wake of military liberation and was hastened, as it was vital to clean out the rear of the army and make the areas near the frontline safe. That way, the purge possessed not only a judicial aspect, but a military one altogether, in a much more pronounced way that most parts of Europe. In the Kalinin and Moscow provinces, the process started as early as mid-December 1941 and was obviously designed as part of the counter-offensive, in the context of the Moscow battle. Unlike in France and Belgium, no allied troops could observe how the locals dealt with their "traitors." This, too, made a significant difference.

Lastly, in the USSR no political struggle followed the liberation. The reign of the Party-State power was not shaken by the war, as other options were compromised by their collaboration with the brutal Nazi occupation and never obtained from Berlin the necessary autonomy which could have made them convincing and attractive. ${ }^{8}$ Furthermore, the resistance movement was taken over by the state, and if some local partisan leaders enjoyed wide autonomy due to the distance from Moscow, they did not manage to constitute a political alternative in the postwar USSR. ${ }^{9}$ The central power never left Moscow, except in October-

7. Nicolas Werth, Les procès de Moscou: 1936-1938 (Bruxelles: Editions Complexe, La mémoire du siècle, 1987).

8. Alexander Dallin, German Rule in Russia 1941-1946: A Study of Occupation Politics (Basingstoke: Macmillan, 1986, first published 1957); Dieter Pohl, Die Herrschaft der Wehrmacht: deutsche Militärbesatzung und einheimische Bevölkerung in der Sowjetunion 1941-1944 (München: R. Oldenbourg Verlag, 2008); Theo J. Schulte, The German Army and Nazi Policies in Occupied Russia (Oxford/New York/Munich: Berg Publishers, 1989); Frank Golczewski, "Die Kollaboration in der Ukraine," in Kooperation und Verbrechen: Formen der "Kollaboration" im östlichen Europa, 1939-1945 (Göttingen: Wallstein Verlag, Beiträge zur Geschichte des Nationalsozialismus), 19 (2005): 151-182.

9. See Kenneth D. Slepyan, "The People's Avengers": Soviet Partisans, Stalinist Society and the Politics of Resistance, 1941-1944 (University of Michigan, 1994). However, we must remind the reader that postwar armed struggle against the "nationalists" in the Western parts of the Soviet Union was closely associated with retribution of collaborators in these areas. For example, Ukrainian nationalists (OUN, UPA) collaborated with the Nazis at the beginning of the war; although they were soon repressed by the Germans who disliked their strong claim for autonomy, they remained fierce opponents to the Soviet regime. The decree of the Presidium of the Supreme Soviet of the USSR dated September 21, 1945, abolished the "state of war" throughout the USSR, except for the Baltic republics, Western Ukraine and Belarus (Iurii M. Kachevskii, "Ugolovnoe pravo voennogo perioda," [The criminal legislation during the war period] Vestnik MGU, 3 [May-June 1985]: 23-31). 
November 1941 — and this concerned only a part of the higher institutions. It clearly called for resistance right from the start: the most famous instance is Stalin's speech of July 3, 1941. That way, no ambiguity remained about the expected correct behavior.

However, some factors make this purge different from the previous ones. First, the reality of the crimes prosecuted; then, the echo of the retribution at the international level. During the whole war, debates opposed the Big Three about the nature and method of punishment for Axis war criminals and their accomplices. The discussion about the penal responsibility of these men was led with the underlying preoccupation of the international image of the future victors, and with the prospect of a common judgment of the main criminals. ${ }^{10}$ The Soviet wanted to find common ground with their allies, and in many ways they contributed greatly to the Nuremberg juridical concepts. ${ }^{11}$ But some of their purposes ran against Western principles or interests. That element gives a specific color to their political repression.

The present contribution focuses on the juridical device used to punish civil collaborators during the liberation of occupied territory at this stage of the conflict. ${ }^{12}$ Our phrase "civil collaborators" points to people who remained on occupied territory and were appointed to various local collaborating administrations, local police troops, or were charged afterwards of denunciating Soviet citizens to the Germans. We exclude such specific units as those of Vlasov's army, essentially composed of prisoners of war (POWs). In other words, we encompass "minor" as well as "major," collaboration, but only on the part of civilians who remained on occupied territory. We focus on the overall legislation and procedures, and leave aside the huge question of the punishment of entire minority groups such as the Crimean Tatars, peoples of the North Caucasus, as well as the sense-laden relationship between collaborators' retribution and fight against Ukrainian, Polish and Baltic nationalists. These repressions, enacted from 1943 up to the late 1940s, marked the passage from social and political purge to comprehensive cleansing of entire suspect minorities from the victorious society. ${ }^{13}$ Thus, our case study concerns a central Russian province deprived of significant minorities.

10. Aleksandr E. Epifanov, Otvetstvennost' gitlerovskikh voennykh prestupnikov i ikh posobnikov V SSSR (istoriko-pravovoi aspekt) [Criminal proceedings against hitlerite war criminals and their helpers in the USSR (historical and legal aspects)](Volgograd, 1997); Georges Ginsburgs, Moscow's Road to Nuremberg: The Soviet Background to the Trial (The Hague/Boston/London: Martinus Nijhoff Publishers, 1996); Ariel J. Kochavi, Prelude to Nuremberg: Allied War Crimes Policy and the Question of Punishment (Chapel Hill/London: The University of North Carolina Press, 1998).

11. Francine Hirsch, "The Soviets at Nuremberg: International Law, Propaganda, and the Making of the Postwar Order," The American Historical Review, 113, 3 (2008): 701-731.

12. For a study of retribution carried out by partisans in occupied territory, see Masha Cerovic's contribution, in the present volume.

13. The concept was studied in Amir Weiner, Making Sense of War: The Second World War and the Fate of the Bolshevik Revolution (Princeton/Oxford: Princeton University Press, 2001). 
That category already encompasses a very large number of citizens. Specialists consider the whole number of civilian collaborators punished after the liberation as turning around 500,000. The data about punished collaborators remain highly controversial. From 1941 to 1954, according to Central Military Procuracy figures, 333,108 Soviet citizens were charged with Article 58-1a (treason to the Motherland) of the Russian Penal Code or other republics' similar articles. ${ }^{14}$ To these figures, one must add the unfortunately unknown ${ }^{15}$ number of those condemned for "assistance to the enemy" (Article 58-3), and the more than 36,065 Soviet individuals concerned by the 1943 Decree, devised to punish violent war crimes perpetrated by invaders and their local followers. ${ }^{16}$ Those data are only indicative, because first, they are incomplete (some years are lacking) and second, they do not include sentences given by other jurisdictions beside military tribunals (the Special Conference of the People's Commissariat of Internal Affairs NKVD - and ordinary courts after 1945).

The main texts concerning the purge were drafted in 1941-1943. But the ground work of the retribution was set in the 1920s and 1930s. Thus the first question concerns the specificity of that purge in comparison with the previous ones. During the war, political retribution condemned actual crimes, and not hypothetic ones committed by indefinite groups. Did the crime of collaboration bring about an adaptation of existing legislation? What was legally, politically and socially at stake? The legal foundations of the purge reveal a variety of goals for the retribution, as well as features making it specific in Europe. The combination of these goals added further complexity to the difficult task of punishing collaboration while trying to restore law. The relevant texts were found in recently published collections of documents, as well as in the archives of the Soviet Prokuratura, Supreme Court, NKVD, and the State Defense Committee.

Then we shall turn to judicial practice and the problems which arose in 19421943. Once again, directives and resolutions at the higher levels of the political and judicial apparatus cast the first light on this process. A selection of concrete cases tried in the Kalinin province reveals the mechanisms of the purge in the field. ${ }^{17}$ They point to repressive traditions in NKVD investigations, as well as specific problems encountered while dealing with collaboration crimes.

14. A.E. Epifanov, Otvetstvennost' za voennye prestupleniia, sovershennye na territorii SSSR $\checkmark$ period Velikoi Otechestvennoi Voiny (istoriko-pravovoi aspect) [Responsibility for war crimes committed on the territory of the USSR during the Great Patriotic War (historical and legal aspects)] (M.: Akademiia Upravleniia MVD Rossii, 2001, 382).

15. In the files we looked at, Article 58-3 was mixed with other points of Article 58, or just did not appear as such (funds of the Ministry of Justice of the Russian State Archive, GARF [Gosudarstvennyi Arkhiv Rossiiskoi Federatsii], f. 9492, on the Gulag administration, f. 9414, on the Supreme Soviet, f. 7523).

16. Epifanov, Otvetstvennost' za voennye prestupleniia..., p. 383. Soviet citizens made up about $60.5 \%$ of the condemned under this Decree.

17. The proceeding records are kept in fund 9849 of the TKHDNI (Tverskoi tsentr khraneniia dokumentatsii noveishei istorii - Tver' Center of Documents of Contemporary History). 
Finally, we shall try to see whether the Soviet purge followed the European common evolution: harshness in the first stage, then softening and rectifications of previous radical sentences. ${ }^{18}$ The April 1943 Decree condemning violent war crimes perpetrated by invaders and their local followers appears as a turning point. It distinguished Nazi atrocities from usual brutalities committed during an occupation, and created new, degrading penalties. It brought the question of the repression of collaborators to the foreground in a context of international debate about the conduct of war and punishment of war criminals, and in an internal context of restoration of Soviet power in large areas. But it also emphasized existing interrogations about the just punishment of various degrees of collaboration issuing from the three chief institutions of justice: the Supreme Court, the People's Commissariat of Justice, and the Procuracy.

\section{Legal foundations}

When studying the normative texts and judicial apparatus of this purge, one is stricken by the lack of reflection or debate - even purely juridical - on the notion of collaboration itself. In Western Europe, the reflection started as early as 19421943; it involved political forces as well as jurists, and revealed the problems that collaboration crimes created to institutions of criminal law. The main questions dealt with the fate of the worst traitors (summary shooting or legal action in full respect of usual procedures?), the types of procedures to be taken against minor traitors, the retroactivity of new laws, etc. One can conjecture that such a striking absence may be due to the secrecy pervading the topic in the Soviet Union. ${ }^{19}$ But more probably, the explanation lies in the specificity of Soviet penal legislation. Collaboration was just one form of "treason to the Motherland," such as described in Article 58 of the 1926 Penal Code.

\section{An old legal basis}

In most European liberated countries, political retribution against collaborators generated a need for new legislation, even in the field of administrative purge where precedents already existed. ${ }^{20}$ While the most serious crimes were often tried under the articles of treason (Articles 75 and 79 in the French code, 118bis in the

18. In Belgium, for instance, some 1945 texts began to soften the repression (decree-law of May 25, 1945), while a policy of royal pardon and early release developed in March 1947: Huyse, Dhondt, La répression des collaborations..., 161-180.

19. Archives of the Defense Ministry of The Russian Federation, where the documents of the military courts and of the Central Military Procuracy are kept, are inaccessible to most researchers - as are the Presidential Archives of the Russian Federation, still considered as most classified files.

20. Paul Gerbod, Les épurations administratives, $X I X^{\mathrm{e}}$ et XX $X^{\mathrm{e}}$ siècles (Genève: Droz, 1977). 
Belgian one: intelligence avec l'ennemi), other crimes created difficulty. Some actions can be qualified as compromise of principles, vileness and lack of national pride. But they did not bring heavy or direct consequences. For those types of offense, executive powers devised decrees (Czech provinces), orders (France), decree-laws (Belgium). These texts made provision for specific penalties against incivisme in Belgium (lack of patriotism), indignité nationale in France (national indignity), offenses against national honor in Czech provinces. ${ }^{21}$ The texts describe the crimes in the following words:

Whoever, during the period of heightened danger to the republic [...], undermined public morale by unbecoming behavior insulting to the national sentiments of the Czech or Slovak people, will be punished - if the act is not a criminal offense punishable by the courts - by District National Committees with up to one year in prison, a fine up to 1,000,000 Czechoslovak crowns, or public censure, or with two or three of these punishments. ("Small Decree," October 27, 1945)

Art. 1. Is guilty of national indignity and punished by the criminal sentence provided for in Article 23 hereinafter, without prejudice to the other criminal sentences or to the penalties that he would furthermore incur if the charges against him would have constituted infractions of the penal law in use on June 16, 1940, every French citizen who has, after June 16, 1940 either knowingly brought in France or abroad a direct or an indirect assistance to Germany or its allies, either undermined the national unity or the liberty of French people, or the equality between them. (De Gaulle's order of December 26,1944)22

Whereas the Czech decree did not give any precision about the types of offense gathered under the expression "unbecoming behavior," the French order, as well as the Belgian decree-law, listed concrete actions such as "being a member of one of the governments from June 1940 to the establishment of the temporary government of the French Republic in metropolitan France," "occupying a leading position in the central, regional or local organs of propaganda" or of "Jewish questions" of these governments, being a member (after January 1, 1941) of a collaboration organization, even passively (a list of precise organizations is given), etc. The condemned actions were not punishable according to the prewar penal codes, which did not make provision for such offenses. Therefore, the new texts had a retroactive effect condemning actions which were not legally reprehensible when they were committed. The penalties established had a past in some of these countries, but had ceased to be in use for several decades. For example, French dégradation nationale deprived the citizen of his civil rights, and sometimes of the right to practice his profession or occupy administrative or leading positions. The

21. Huyse, Dhondt, La répression des collaborations..., 30-33, 41-46, 134; A. Simonin, "L'indignité nationale: un châtiment républicain," in Marc-Olivier Baruch, ed., Une poignée de misérables : L'épuration de la société française après la Seconde Guerre mondiale (P.: Fayard, 2003, 37-60); Frommer, National Cleansing, 186-227.

22. For the Small Decree, see Frommer, National Cleansing..., 371-372; for the French order, see Journal officiel de la République française, 27 décembre 1944, 2076-2078. 
sentence could be for life or a term. In the first case, the condemned person was excluded from the community of citizens: his situation reminds one of "civil death" - a disposition abolished in 1854 - though in an attenuated form. The aim of these sentences was to exclude from public life people who, without having committed a concrete crime, were no longer considered full-fledged citizens. In each country, that kind of sentence was delivered by a special jurisdiction, different from the organs condemning under the penal code: chambres civiques in France, auditorat militaire in Belgium, District National Committees in Czech provinces. In France, being prosecuted by a tribunal (cour de justice) did not protect against further prosecution by a chambre civique, and reciprocally. Finally, we must mention that the government of Czechoslovakia decreed the expulsion of all ethnic Germans and banished a great number of Hungarians, thus achieving a "collective punishment of an entire national minority". As Benjamin Frommer pointed out, "expulsion and prosecution were often seen as alternatives." Collective retribution of national minorities also occurred in the Soviet Union, with the deportation of entire populations in the North Caucasus, Crimea, etc. ${ }^{23}$

In the USSR, no innovation was necessary. The first chapter of the 1926 Penal Code already made provision for all types of "counterrevolutionary" crimes, that is, political offenses ranging from "agitation and propaganda" to treason to the Motherland (see appendix). Sentences combined detention terms and deprivation of rights (described in Article 31) with confiscation of property (as secondary penalties). In some cases, qualified as the most serious ones, the death penalty and "proclamation as enemy of the working people" (leading to deprivation of Soviet citizenship and banishment) replaced camp or prison terms. The general principles of the Code also made provision for strict isolation, banishment from a locality or from a Soviet republic, public blame, dismissal from a public office, banning from certain professions, etc. (article 20). That is to say that a large array of sentences could be used, and specific political penalties already existed. Moreover, the principle of "analogy" (article 16) stipulated that

If one or another socially dangerous action is not directly provided for by the present Code, then the basis and limits of responsibility incurred must be defined according to the articles of the Code which make provision for crimes considered as the most similar in nature. ${ }^{24}$

23. See N.L. Pobol', P. M. Polian, Stalinskie deportatsii: 1928-1953 [Stalinist deportations: 1928-1953] (M.: Izd. Materik, Mezhdunarodnyi fond "Demokratiia," 2005); Nikolai F. Bugai, Reabilitatsiia repressirovannykh grazhdan Rossii (XX-nachalo XXI veka) [Rehabilitation of the repressed citizens of Russia (XX-beginning of the XXI century)] (M.: MSNK-press, 2006); Weiner, Making Sense of War, 2001. We must underline that these repressions were not accomplished according to laws, but following executive acts (in most cases, State Defense Committee resolutions).

24. A. Trainin, V. Men'shagin et al., Ugolovnyi Kodeks RSFSR': Kommentarii [The penal code of the RSFSR: comments] (M.: Iuridicheskoe izdatel'stvo NKIu SSSR, 1946, 2nd edition). 
This specificity finds its explanation in the first and second articles of the Code:

RSFSR penal law is designed to protect the socialist state of the workers and the peasants [...] Is recognized as socially dangerous any action or inaction directed against the Soviet regime or violating the legal order established by the power of the workers and peasants for the time of the transition to a communist regime.

That way, Soviet law was conceived as a mere means of achieving the desired communist society. Law was not above state, but at its service, and that principle was officially claimed by Soviet jurists. ${ }^{25}$ Theoretically, law was to disappear when communist society was achieved. The "law nihilists," including the author of the 1926 Penal Code Krylenko, accepted the reinforcement of the state, necessary to impose planification and collectivization, but opposed the strengthening of the legal system. For them, planification was to replace law and the socio-economic policy would guarantee the realization of regulating norms. In the mid-1930s, they were defeated by the rival school of thought: Vyshinskii's demand for codification and reinforcement of the law. The Soviet Prosecutor understood the trend of the day: consolidating the state, or rather Stalin's power, using all the possibilities provided by the law. It may seem a contradiction that the main prosecutor of the famous Moscow trials was also a fierce proponent of a strengthening of the legal system. ${ }^{26}$ Anyway, whatever the law may be, much depends of the way it is implemented. Falsification of cases in the 1928-1938 repressions show that political direction used the law to reach political ends and send strong signals.

Prosecution of collaboration crimes does not escape that examination of issues. On the one hand, all forms of assistance to the enemy were treated as "treason to the Motherland" without further legal devising. On the other hand, as we shall see, higher judicial organs were at pain to qualify adequately minor collaboration and sought an adequate position.

Up to the 1943 Decree, all the crimes of civilian collaboration were tried under points $1 \mathrm{a}$ and 3 of Article 58. Article 58-1a was completed by the Central Executive Committee's (henceforth TsIK) resolution of June 8, 1934. It defined straight crimes of "treason to the Motherland," that is, "any action committed by citizens of the USSR at the expense of the Soviet military force, Soviet state sovereignty or integrity, such as espionage, divulgation of a state or military secret,

25. Jacques Bellon, Le droit soviétique (P.: PUF, Que Sais-Je, 1967, first published 1963); Robert Conquest, ed., Justice and the Legal System in the USSR (London/Sidney/Toronto: The Bodley Head, Soviet Studies Series, 1968); A.A.Gertsenzon, Sh. S. Gringaus, N.D. Durmanov, N.D. Isaev, M.M. Isaev, B.S. Utevskii, Istoriia sovetskogo ugolovnogo prava [History of the Soviet criminal legislation] (1947 edition reprinted by Allpravo.ru, 2003).

26. An interesting article by Arch Getty studies the topic of the use of justice by the designers of a politics of terror, and of the fluctuation between a trend towards a modernization of justice and the resort to extralegal proceedings in the 1930s. According to him, the system has tended towards modernization within the limits of its political aims, especially since 1933, but the complexity of the Stalinist political system simultaneously generates uncontrollable repressive campaigns. Arch Getty, “'Excesses Are Not Permitted': Mass Terror and Stalinist Governance in the late 1930s," The Russian Review, 61 (January 2002): 113-138. 
going over to the enemy, defection to another country." 27 The list established by Article 58-1a did not specify what to do with such different forms of "going over to the enemy" as joining local police without committing brutalities against Soviet citizens or joining local police and taking part in the implementation of the Shoah... The same remark can be made about Article 58-3. It deals with "collusion with a foreign state or its delegates with counterrevolutionary intentions and any kind of assistance provided to that state or any state fighting against the USSR." That point uses a wide definition of the crime, speaking of "any kind of assistance" without any precisions as to the nature of the assistance provided. According to a famous Soviet jurist, Aron Trainin, the intention accounting for the assistance provided to the foreign state does not matter. If the Soviet Union was in a state of war with the latter, any kind of help was a counterrevolutionary crime. Trainin goes on: in wartime, assistance to the enemy, whatever it might be, was directed against the USSR and had to be tried under Article 58-1a (if the author was a Soviet citizen). Thus these articles were used in the spirit of Bolshevik legal theory and judicial practice: minor forms of antipatriotic behavior were prosecuted under those provisions, no incivisme or indignité nationale were created. Moreover, Article 16 (analogy) could ease the qualification of various antipatriotic acts under Articles 58-1 and 58-3. But, as far as we know, recourse to the principle of analogy was not needed in our cases of collaboration. The "small fry" was liable to suffer the penalties defined in Article 58, and the severity of the sentence was the sole indicator of the levels of collaboration.

Two remarks can be made. First, in wartime, "any kind of assistance provided to that state or any state fighting against the USSR" was relevant of the sentences mentioned in Article 58-1a instead of those described in Article 58-3: that is to say, capital punishment or the longest camp term existing in the Soviet Union (10 years $)^{28}$, instead of the shorter camp terms foreseen in case of mitigating circumstances. Consequently, in theory very different crimes could be charged with the same penal article. An individual working for a German kitchen could go under the same article as someone serving in the German police.

However, and that is the second point, if the existing law did not precisely define the nature of the crime, it was because the courts enjoyed the prerogative of determining the "social danger" of both crime and criminal. Article 45 of the 1926 Penal Code says: "When the court inflicts to the defendant a judicial-corrective measure of social defense, it follows: (1) the indications of the general part of the present Code; (2) the limits fixed in the article of the special part which makes provision for the given type of crime; (3) its socialist legal conscience, considering

27. Trainin, Men'shagin et al., Ugolovnyi Kodeks RSFSR...

28. A resolution of the Central Executive Committee dated October 2, 1937 made provision for lengthy sentences up to 25 years in the cases of espionage, wrecking and diversionist acts: Izdanie Verkhovnogo Soveta Rossiiskoi Federatsii, Sbornik zakonodatel'nykh i normativnykh aktov o repressiiakh i reabilitatsii zhertv politicheskikh repressii [Collection of the Legislative and normative Acts about persecution and rehabilitation of the victims of political repressions] (M.: Izdatel'stvo "Respublika," 1993), 35. 
the social danger of the crime, the circumstances of the case and the personality of the defendant." Indeed, "the conception of guilt was deemed to be integrally bound up not only with the social danger of the crime but with the socially dangerous character of the criminal." 29 The Soviet legislator could have covered the question of social danger in establishing corpora delicti but another choice was made: "the courts must pronounce not only on the presence of crime, as defined in the attributes and criteria of a given corpus delicti, but also on the question of social danger." If, in any legal system, a degree of elbow-room is left to the inner conviction of the judge, in the Soviet system this margin is extended, probably because of the core principles delineating the purpose and the form of law. Anyway, in that situation the fate of a defendant heavily depends on the qualification and the independence of the judges, as well as on the way the preliminary inquiry and the trial itself go off.

\section{The conditions of prosecutions}

According to the decree of the Presidium of the USSR Supreme Soviet dated June 22, 1941, in all the territories declared "in state of war," military justice replaced ordinary courts in the cases of state, and several other categories of crimes. Furthermore, military powers, invested with high authority, could refer to the military tribunals as many penal cases they assessed was necessary. ${ }^{30}$ One specificity of military courts is that no appeal is possible; the prosecutor's regular surveillance can only submit an appeal to higher military tribunals, following this hierarchical procedure: superior military tribunal (front tribunal), then Military College of the USSR Supreme Court, and finally, Plenum of the Supreme Court. But as early as 1934 crimes of treason, espionage and terrorist acts had come under special jurisdictions and procedures. ${ }^{31}$ This constitutes the first link between the 1930s' great purges and the war purges. ${ }^{32}$ Indeed, TsIK's resolution of July 10, 1934, established that crimes of treason, espionage, acts of terrorism and diversion (Article 58-1, 58-2, 58-333, 58-6, 58-8, 58-9 of RSFSR Penal Code) should be tried

29. Conquest, ed., Justice and the Legal System, 75.

30. Sbornik zakonov SSSR i Ukazov Prezidiuma Verkhovnogo Soveta SSSR za 1938-1961 [Collection of the Acts of legislation of the USSR and Decrees of the Presidium of the USSR Supreme Soviet for 1938-1961] (M.: 1961,418-421).

31. Izdanie Verkhovnogo Soveta, Sbornik zakonodatel'nykh i normativnykh aktov..., 33-34, 64-65.

32. However, the Great Purges trials did not make much use of Article 58-1a: they mostly referred to 58-6, 58-8, 58-9 and 58-11.

33. There is some confusion in the 1934 text: whereas it lists the articles concerning espionage and various forms of terrorism (Art. 58-6, 58-8, 58-9), it does not give details about "treason to the Motherland." According to Anatolii Muranov and Viacheslav Zviagintsev, since July 10, 1934, all counterrevolutionary cases had come under the military tribunals and the Military College of the Supreme Court. Although these authors are probably well informed - the former was head of the Direction of military tribunals in the 1980s, and the latter was his deputy - they do not provide documents confirming this assessment. Therefore, we follow Trainin's remarks on the Penal Code to include in this category, beside Art. 58-1, Art. 58-2 and 
by sector military tribunals and by the Military College of the Soviet Supreme Court. All those cases were to be investigated by the NKVD, under the control of the military Prokuratura (Prosecutor's office). According to several authors, in fact the professionals of justice had less and less authority on the NKVD's procedures. Their attempts to mitigate the arbitrary character of preliminary inquiries led nowhere or to their own dismissal or prosecution. ${ }^{34}$ A project proposed by Vyshinskii on March 4, 1940, illustrates how he conceived the prerogatives of the different organs involved in a judicial procedure instructed by the NKVD. The point discussed was the procedure of liberation of a suspect at the stage of the preliminary inquiry. The party should give its opinion about it, but that opinion should not appear in the proceeding records of the case. The closing down of prosecution and the subsequent release of the suspect decided by the Prokuratura should receive the agreement of the NKVD. And if a disagreement remained, the party's Central Committee was supposed to settle the conflict. ${ }^{35}$ That project was not ratified, possibly because it underlined too clearly the Party's prerogative in

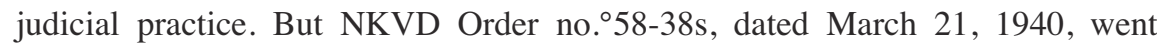
further: not only was the prosecutor unqualified to close a case without the authorization of the NKVD, but an acquittal sentence itself could not make a defendant free if the NKVD opposed the defendant's release. ${ }^{36}$ This order was abolished in August 1953. It was based on a Prosecutor's directive dated March 20, 1940, which stipulated that after the court acquitted the defendant, judicial organs had to "ask the NKVD if it had 'any objections' independently from the exculpating sentences." 37 Later, this procedure was extended to all cases investigated by the secret police, but not on purportedly political affairs in which the ordinary police or the Procuracy conducted inquiries. ${ }^{38}$ The implementation of these directives did not go without problems. The NKVD had a tendency to give them an excessively broad

58-3. Anatolii I. Muranov, Viacheslav E. Zviagintsev, Dos'e na marshala: iz istorii zakrytykh sudebnykh protsessov [The dossier on Marshal: from the history of closed trials] (M.: Andreevskii Flag, 1996).

34. A. Muranov, V. Zviagintsev, Sud nad sud'iami (osobaia papka Ul'rikha) [The trial over the judges (special file of Ulrikh](Kazan: Izd. "Kazan," 1993); Rasprava: Prokurorskie sud'by [Reprisals against the Prosecutors] (M.: Iuridicheskaia literatura, 1990). We found one documented example of such pressures. In 1949, K.V. Suvorov, a military tribunal president, was dismissed and prosecuted because he showed a tendency to "smother these cases [counterrevolutionary] by criticizing the methods of investigation of the military counterespionage organs and of the MGB." He often acquitted defendants or tried to make them disprove their previous declarations in order to discredit the preliminary investigation. GARF, f. 7523, op. 65, d. 75, 1. 1-6.

35. Vladimir N. Khaustov, Vladimir P. Naumov, N.S. Plotnikova, Lubianka: Stalin i NKVDNKGB-GUKR "Smersh" (1939- mart 1946) [Lubjanka: Stalin and NKVD-NKGB-GUKR "Smersh"] (M.: Izd. Materik, Mezhdunarodnyi Fond "Demokratiia," 2006, 143-144).

36. GARF, f. 8131, op. 32, d. 2229, 1. 95 and 2232,1. 10-11.

37. GARF, f. 8131, op. 37, d. 210,1. 7, op. 38, d. 46,1. 57; f. 9492, op. 1a, d. 63,1.46, quoted in Gabor Rittersporn, "Extra-Judicial Repression and the Courts: Their Relationship in the 1930s," in Peter H. Solomon, ed., Reforming Justice in Russia, 1864-1996: Power, Culture, and the Limits of Legal Order (Armonk/London: M. E. Sharpe, 1997, 207-227).

38. GARF, f. 8131, op. 37, d. 210,1.1, op. 38, d. 43,1.119; f.9492, op. 1a, d. 63,1. 167. 
interpretation, so that it refused to liberate people acquitted by the Supreme Court of the Russian Federation, although the original instruction applied only to rulings at the first instance. ${ }^{39}$

Perhaps one of the most significant signs of the trend was the appointment, on July 8, 1940, of V.M. Bochkov as USSR Prosecutor. A 1938 graduate of the Frunze Academy, Bochkov had thus far been occupying leading positions... at the NKVD, first as chief of NKVD prisons, then as chief of a NKVD special department (in the army). In other words, Bochkov came from the NKVD and not from judicial circles..$^{40}$

In August 1940, a resolution was taken by the Political Bureau (Politburo) of the party's Central Committee: "On traitors to the Motherland." This text strengthened the fight against traitors, especially defectors and soldiers. Investigation was limited to ten days, then the military tribunal had two days to pronounce a judgment, and the Military College of the Supreme Court had to examine the sentence right away. ${ }^{41}$ Such a text is characteristic of Soviet repressive campaigns. Those 1940 texts are important, as they show that the apparent return to legal procedures decided in November 1938 was forgotten as the winter war ended and the Great Patriotic War came closer. New large repressions were shaping up as the danger became clearer.

In December 1934 and September 1937 respectively, TsIK's resolutions had devised similar expeditious procedures for crimes of terrorism and crimes of wrecking and diversion. ${ }^{42}$ Repression of the members of a traitor's family was extended in 1940 and 1942, after being reinforced in June 1934 and August 1937.43 The Decree of the Presidium of the Supreme Soviet of December 7, 1940, made provision for a three-to-five-year exile in distant areas of the Soviet Union of the family of an individual, civilian as well as military, who escaped abroad. ${ }^{44}$ In December 1941, a similar fate was decreed for the families of traitors who enlisted in the German repressive organs, while the resolution of the State Defense Committee of June 24, 1942 was directed against the families of all kinds of collaborators. The only circumstance that could prevent these families from being deported was the presence in their midst of a Soviet fighter (regular soldier or

39. AP RF (Arkhiv Prezidenta Rossiiskoi Federatsii) f. 3, op. 57, d. 59, 1. 51-52). See also: Khaustov, Naumov, Plotnikova, Lubianka..., 184.

40. Michael Parrish, The Lesser Terror: Soviet State Security, 1939-1953 (Westport/London: Praeger, 1996): 27-28.

41. Khaustov, Naumov, Plotnikova, Lubianka..., 184.

42. Sbornik zakonodatel'nykh i normativnykh aktov o repressiiakh..., 33-34, 64-65.

43. The June 8th, 1934 resolution of the TsIK of the USSR added Point C to Art. 58-1. Point C made provision for various penalties against the members of the families of soldiers who fled abroad. NKVD Operative Order no. 000486, dated August 15, 1937, foresaw punishment of traitors' wives. Sbornik zakonodatel'nykh i normativnykh aktov o repressiiakh..., 86-92.

44. Khaustov, Naumov, Plotnikova, Lubianka..., 203. 
partisan). ${ }^{45}$ These draconian measures were cancelled by a special Politburo decision as late as October 1956.46

To be definitely convinced that the war purges of collaborators operated like those of the 1930s, let us examine the various instructions given to the police and judicial apparatus about these crimes.

An article published in September 1941 in the legal journal Sotsialisticheskaia Zakonnost" (Socialist Legality) said that "The fight against this most serious category of crimes [counterrevolutionary crimes] must be accomplished with special determination and ruthlessness. The enemies of the people and their accomplices must be pitilessly exterminated." ${ }^{47}$ Going further, the author explained that during the war prosecutors must attach peculiar importance to state crimes. They must take them under special consideration from the beginning of the investigation to the pronouncement of the verdict. The aim was to speed up the repression of these criminals. To this end, the decree of June 27, 1941 granted the military councils of fronts, in exceptional cases, the right to ignore the Military College of the Supreme Court and ratify death sentences. These prerogatives were extended to the military councils of armies and corps, and to divisional commanders in July and September $1941 .{ }^{48}$ Last, no appeal of the sentence could be made: the people condemned to death could only beg for the mercy of the Supreme Soviet. The purpose here was probably to relieve the prisons and judicial organs near the front from the burden of such prisoners and the danger they represented.

Another characteristic feature of the military procedure was the absence of defense from the beginning (the arrest) to the end (the trial). As for the prosecutor, we saw that he was supposed to control the preliminary inquiry, that is, confirm the order of arrest and the charge against the defendant, and attend pre-trial examinations. But he did not attend the trials. The famous jurist A.M. Strogovich, author of several studies and notably of Voennye tribunaly sovetskogo gosudarstva (Moscow, 1942), wrote in February 1943 to the USSR People's Commissar of Justice and the Prosecutor to criticize this fact. According to him, the absence of the prosecutor is harmful in such complicated cases where the evidence is weak and the educational dimension is important. ${ }^{49}$ Indeed, in the Soviet Union, trials had to be educational; concerning ordinary military justice (excluding counterrevolutionary crimes), the custom was to announce or apply the sentence publicly, in front of the troops..$^{50}$ Prosecutors were expected to pronounce speeches underlining the dangerous

45. See RGASPI (Rossiiskii gosudarstvennyi arhiv sotsial'no-politicheskoi istorii), f. 644, op. 1, d. 17,1. 198 for the 1941 resolution and RGASPI, f. 644, op. 1, d. 40,1. 61 for the 1942 one.

46. AP RF, f. 3 , op. 57 , d. 59,1.73-78.

47. Ia. Umanskii, "O zadachakh prokurorskogo nadzora nad zakonnost'iu rassmotreniia sudami ugolovnykh del," [Tasks of the prosecutor's supervision over the legal proceedings against criminal cases] Sotsialisticheskaia Zakonnost', 6 (September 1941): 5.

48. Epifanov, Otvetstvennost' za voennye prestupleniia..., 193.

49. GARF, f. 8131, op. 20, d. 1,1. 195-196.

50. S.A. Golunskii, Prigovor voennogo tribunala [A verdict of the military tribunal] (Ashkhabad: Voenno-iuridicheskaia akademiia, 1942). 
character of the crime and the purpose of the sentence, and to write articles for the local press. But as far as counterrevolutionary crimes were concerned, publicity was reserved to a selected number of trials, the "show trials." The large majority remained secret.

Finally, the personnel of the military tribunals during the war can be explored, if not really studied. ${ }^{51}$ The few available documents and memoirs suggest a lack of experienced or competent jurists during the war. The number of military tribunals was greatly increased, and the People's Commissariat of Justice, in charge of judge appointments, seems to have been compelled to appoint civilian judges or recently graduated students. ${ }^{52}$ As was frequently pointed out, ${ }^{53}$ the latter did not know the specificities of military justice, and civilian judges were not always professional magistrates. According to several memoirs, the main criterion for appointment as military judge or president of a military tribunal was party membership. ${ }^{54}$ This situation could only reinforce their dependency on the institutions - the party, the NKVD - and to a lesser extent, on the prosecutors.

In other words, the legal and institutional system chosen to prosecute complex crimes such as collaboration left extended prerogatives to the investigative organs and military courts in disarray. As Peter Solomon established for the 1930s, such a system in the Stalinist dictatorship led to "campaign justice," that is, a chaotic alternation of periods of passive resistance on the part of judges and periods of harsh repression. Only the study of judicial practice can allow us understand further the path followed in the repression of collaborators.

51. We found no information in the archives about military judges and prosecutors during the war.

52. L.A. Pavlova, Zhit' - znachit pomnit'... Kniga o sudebnykh rabotnikakh, uchastnikakh voiny $i$ truzhenikakh tyla [To live means to remember... A book about legal employees, participants of the war and workers of the rear] (Ekaterinburg: Bank kul'turnoi informatsii, 2005, pp. 29-30, 39, 56, 60, 100, 131).

53. S.A. Golunskii, Prigovor voennogo tribunala, 1942; Ivan Terent'evich Goliakov, ed., Sovetskoe pravo v period Velikoi Otechestvennoi voiny, chast' II - Ugolovnoe pravo Ugolovnyi protsess [Soviet legislation during the Great Patriotic War, part II: criminal law criminal trial] (M : Iuridicheskoe izdatel'stvo Ministerstva Iustitsii SSSR, 1948); Dmitrii Stepanovich Karev, D.D. Chertkov, Osobennosti sudoproizvodstva $v$ organakh voennoi iustitsii [Peculiarities of the legal proceedings of the military justice] (M.: Izdanie Voennoiuridicheskoi Akademii Krasnoi Armii, 1940).

54. Iakov Aizenshtat, Zapiski sekretaria voennogo tribunala [Memoirs of the secretary of the military tribunal] (London: Overseas Publications Interchange, 1991); A.A. Stukalov, S.Iu. Iushakov, "Front voennykh prokurorov." Kogda rasstrelivali prokurorov: Rasskazy o voennykh prokurorakh ["The front of the war prosecutors." When prosecutors were shot: Essays about war prosecutors] (M.: 2000); A.H. Valiev, Zapiski voennogo prokurora (Kazan: Matbugat Yorty, 2000). 


\section{Judicial practice in the early stage: 1942-spring of 1943}

As we saw, the texts fixing retribution against collaborators made it a part of traditional Soviet political justice. Nevertheless, the unprecedented character of the situation engendered numerous complications when judicial organs attempted to qualify a new crime according to old laws.

Very soon prosecution against collaborators fell into the hands of the NKVD, that is to say a special jurisdiction, from the very first steps of arrest and investigation up to the trial. The inquiry was led by territorial NKVDs or, when they had not yet come back from the areas near the front, to NKVD special departments in the army. This made a difference with ordinary military prosecution, performed by military commanders or their assistants. As for the courts, the cases prosecuted very close to the frontline or where civilian authorities did not exist, were judged by military tribunals. Concerning the others, between June 1941 and January 1942, several texts transferred more and more cases from usual military courts to military courts of NKVD troops and to the Special Conference of the NKVD (when, for "operational reasons," they could not be judged in a trial).$^{55}$ In November 1941, NKVD Chief Beria asked the State Defense Committee to allow the Special Conference (OSO NKVD) to sentence to death people charged with Article 58 and some points of Article 59. It was done on November $17,1941.56$

As soon as the first liberations came into view, Beria devised a special order on the NKVD's tasks in freed territory. ${ }^{57}$ Order no. ${ }^{\circ} 001683$, dated December 12 , 1941, stated that the chiefs of regional NKVDs should reorganize local organs immediately after the liberation. Then, priority was given to the arrest of "agents of German espionage organs" who remained in the Soviet rear to inform the Germans beyond the frontline. Any collaborator was suspected to be an agent. To identify them, the Soviet police had to get in touch with Soviet patriots, agents, and partisans who were left in the German rear and knew who the traitors were. In February 1942, Beria ordered that any document on Nazi occupation and atrocities should be collected by the NKVD, either in Moscow or the provinces.58 That way, NKVD agents were supposed to possess as much information as possible to enable them to imprison dangerous elements. The seriousness of the danger was further

55. See General Prosecutor's Order no. 104/64 dated June 27, 1941 (GARF f. 9492, op. 1, d. $62,1.116$ ) another order dated 1941 about the modes of inquiry and deferring to the courts of the cases coming within the remit of the military tribunals in the regions "in a state of war," and the General military Prosecutor's Directive of January 6, 1942, Epifanov, Otvetstvennost' za voennye prestupleniia..., 190-193.

56. RGASPI, f. 644, op. 2, d. 25,1. 142-143 and RGASPI, f. 644, op. 2, d. 14, 1 .101.

57. Organy gosudarstvennoi bezopasnosti SSSR v Velikoi Otechestvennoi Voiny. Sbornik dokumentov, tom II, kniga 2: Nachalo, 1 sentiabria-31 dekabria 1941 goda [The Soviet security bodies during the Great Patriotic War. Vol. II, book 2: The Beginnig of the War, 1 September - 31 December 1941](M.: Izd. "Rus", 2000, 413-415).

58. SMERSH: Istoricheskie ocherki i arkhivnye dokumenty [SMERSH: Historical essays and archival documents] (M.: Izdatel’stvo Glavarkhiva Moskvy, 2005, 313). 
underlined by an Order of the USSR military prosecutor dated January 6, 1942. Regulating NKVD special departments' work in very recently liberated territory, it advocated harsh retribution against the Germans' accomplices, with or without a trial. A few hours should be enough to discover the crime and prosecute. Liberalism was strictly forbidden. However, military prosecutors were expected to prevent arbitrary actions against the convicted. ${ }^{59}$ Such haste might be explained by the instability of the frontline at that period of the war. But it is also indicative of a determination to avoid wild retaliation.

A sample of proceeding records kept in Tver archives will cast some preliminary light on the police and justice practices in the first period of the war. ${ }^{60}$ Tver (Kalinin province), $250 \mathrm{~km}$ away from Moscow, was gradually occupied between July 5 and October 1941. Several districts were freed during the counteroffensive of December 1941-January 1942. The last ones were liberated in July 1944. The province appears to be a good working ground to follow the purging process from the start in 1942 to the end in the 1950's. Unfortunately, available records only show rehabilitated cases, and do not therefore include cases of proven active and serious collaboration. ${ }^{61}$ In other words, our sample is biased, showing inquiry flaws or even complete fabrications. But it provides a good illustration of minor cases of collaboration and the fate of the "small fry" in a confused period of retribution. Most of the prosecutions were conducted in 1942. The first series of arrests appear clearly in the prisons data. Kalinin prisons were evacuated in the fall of 1941: in September, local authorities asked Moscow to evacuate about 1,500 prisoners by train. In December, a report from the head of the NKVD's prisons, Nikol'skii, stated that 2,500 prisoners had been evacuated from Kalinin's prisons: nine out of twelve prisons happened to be on occupied territory. At the end of January 1942, nearly 2,700 prisoners from the Kalinin province were detained in the Vologda region. ${ }^{62}$ Two weeks later, NKVD Order no. 00351 commanded the immediate transfer to the rear of prisoners from the front who had been hastily condemned or were waiting for the result of their appeal. ${ }^{63}$ However, at the same time, Kalinin prisons on freed territory held 4,373 prisoners, when the limit was fixed at 2,500.64 Supposing that these 4,373 were re-evacuated people makes no sense, as the efforts

59. Epifanov, Otvetstvennost' za voennye prestupleniia..., 193.

60. TKhDNI, f. 9849: proceeding records of rehabilitated individuals and filtration files, 1920s-1980s. No inventory of the archives, which contain more than 50,000 records, existed when we worked on them, so we identified collaborators' cases using Kniga pamiati zhertv politicheskikh repressii Kalininskoi oblasti [Memory book of the victims of political repressions in Kalininskaya oblast], vol. 2 (2001) and asking the regional FSB agency about the existence of a record on people evoked in various documents.

61. Such records were studied by A.E. Epifanov, 2001. One will find witness accounts and statements by the defendants in the archives of the "Extraordinary State Commission for Ascertaining and Investigating Crimes Perpetrated by the German-Fascist Invaders and their Accomplices" (ChGK) in GARF, f. 7021.

62. GARF, f. 9313, op. 1, d. 21,1.181, 184-85,219, 225.

63. GARF, f. 9401, op. 1a, d. 110,1.160.

64. GARF, f. 9313 , op. 1, d. 42. 
were aimed at removing dangerous people from the frontline area. So we must assume that the prisoners were arrested during the liberation. Out of these 4,373, nearly 1,000 came under NKVD organs: in other words, they were suspected of serious crimes, especially crimes against state security. Most of them must have been collaborators. The number of prisoners detained in Kalinin's prisons kept on rising during the whole year. On June 1, it peaked at 5,388 prisoners and 1,353 for the NKVD. It remained high in July 1942, and began to decrease in August. In late 1942, "only" 4,226 prisoners were kept in the Kalinin province; the number of those coming under the NKVD organs had fallen to 426, but those coming under the Special Conference reached the figure of 323 (only ten in April 1942). That way, the first wave of arrests ended; condemned collaborators were executed or sent to NKVD camps, especially the Rybinsk camp. ${ }^{65}$

These figures reveal that the NKVD zealously implemented received orders. A resolution of the State Defense Committee dated January 4, 1942 replaced military garrisons stationed in liberated towns with NKVD troops. These NKVD garrisons were expected to patrol and provide assistance to the territorial NKVDs in the "task of rooting out enemy agents, traitors and other anti-Soviet elements." A total of 100,000 men were assigned to these garrisons, but this turned out to be insufficient as Beria asked Stalin for extra personnel as early as the end of February. ${ }^{66}$ On January 7, Beria sent an order to Kalinin's First Party Secretary I.P. Boitsov, and to the regional head of the NKVD, D.S. Tokarev. Referring to Order no. 001683 and to the State Defense Committee's resolution of December 27, 1941 (about traitors' families), Beria summoned them to arrest all the policemen and high administrators, and to investigate on their families; to make an inquiry on inferior collaborators and arrest them if necessary. Last, he enjoined them to investigate the close circles of women who met with Germans, in order to identify spies and agents. ${ }^{67}$ Though this text distinguishes between major and minor collaborators on the field, NKVD organs arrested anyone who compromised himself during occupation. This overzealous activity can be explained by old habits of repressive campaigns as well as by the proliferation of orders on the topic, leading the organs to believe that harsh repression was the top priority, notwithstanding nuances between categories. On February 10, 1942, Kalinin's prosecutor sent local prosecutors a directive inviting them to use the passport system to track down traitors in freed territory. ${ }^{68} \mathrm{~A}$ week later, Beria wrote to Stalin that a new passport registration of people in the liberated areas would help unmask German agents and traitors and cleansing localities from alien elements. A State Defense Committee resolution ratified this idea on February 21, 1942. ${ }^{69}$

65. GARF, f. 9313, op. 1, d. 41,1.70-75. The report evoking Rybinsk is dated March 1943.

66. RGASPI, f. 644, op. 2, d. 32,1.11 and d. 41,1.7.

67. TKhDNI, f. 147, op. 3, d. 337,1.1.

68. GATO f. R-2321, op. 6, d. 7,1.11.

69. RGASPI, f. 644, op. 2, d. 37, 1. 146 and RGASPI, f. 644, op. 1, d. 21,1. 152. 
A close study of 40 proceeding records shows that for the town of Kalinin (twenty cases) two thirds of the suspects were arrested between December 18 and December 31, 1941. For the rural districts, the two suspects imprisoned in the district of Zavidovo (near Moscow), were arrested at the same moment. Out of the remaining 30 suspects, 23 were arrested in the first four months of 1942, 23 were tried in the first term of 1942 . For 10 people, the preliminary inquiry lasted less than 10 days. Two records contain no protocol of witness questioning, two contain only one, and most of them, between two and five protocols. Most records are deprived of evidence. In other words, the first wave of repression seems to have been carried out in a great hurry and with peculiar severity: half the defendants were sentenced to death. ${ }^{70}$ Much like what happened in other freed countries in Europe, the cleansing began in a context of anger and haste, while courts were overburdened with a great number of cases. Moreover, in Russia, the first liberations went along with the discovery of appalling Nazi crimes. Our findings in the Kalinin province confirm A.E. Epifanov's statement: quite often, people spontaneously came to Red Army officers or NKVD organs to give testimony of the crimes they saw during occupation. There was indeed a thirst for law and order after Nazi arbitrary rule. ${ }^{71}$ On their part, soldiers and re-evacuated police organs were shocked by the suffering inflicted on Soviet civilians and POWs, and by the large-scale destruction wreaked by the German army's retreat. None of these factors favored quiet prosecutions. Despite the variety of forms of collaboration, places, and even prosecutors, no difference in the approach can be found in our sample. Three suspects were arrested by the army and then transferred to NKVD special departments for inquiry; two of them were executed. Preliminary inquiries carried out by the special departments always led to death sentences, but we do not have enough cases to draw any conclusion (only 3). The regional NKVD recommended death for slightly more than half the cases investigated (11); the figure is similar for district NKVDs. Half the people tried by an army military tribunal, a third of those judged by a NKVD military tribunal, and nearly all of those sentenced by a garrison military tribunal, were executed. The Special Conference sentenced four out of six defendants to death.

Undoubtedly, the most striking feature of these records is the inconsistency of the charges. Serving in an occupation administration, whatever the activity was, justified prosecution and severe punishment. Quite probably, the lack of nuance was partly generated by the paucity of systematized information, at this stage of the war,

70. TKhDNI, f. 7849, dela: 9265s (Belousov and Tikhonchuk), 11480s (Dobrynin), 12439s (Terent'eva), 17426s (Antonov, Zakharov, Grigor'ev, Savel'ev), 17535s (Monikovskaia mother and daughter, Bol'shev, Petrova, Alekseeva), 19183s (Volnushkin), 19600s (Kamenskii), 23437s (Gnatiuk), 26013s (Kozlov and Smirnov), 26752s (Andreev E.), 27003s (Sazonov and Prokhorov), 27219s (Andreev V.), 28046s (Aleksandrov), 28179s (Nikanorov), 28181s (Pyrkov), 28308s (Aksenov), 28498s (Il'in), 28813s (Kop'ev), 28870s (Zolotov), 29748s (Svetogorov), 29942s (Sizikov), 30150s (Korotkov), 30309s (Sergeeva, Apleukhina, Sycheva, Vilinskaia), 33697s (Shikhin and Toporov).

71. Epifanov, Otvetstvennost' gitlerovskikh voennykh...; RGVA (Rossiiskii Gosudarstvennyi Voennyi Arkhiv - Russian State Military Archive) f. 1303k, op. 3, d. 222, 1.33-39 and 41-46. 
about collaborators' concrete duties. Mere contact with the Germans was enough to arouse suspicion of espionage. For example, Varvara Monikovskaia, deputy of the Toropets urban soviet and member of the party, was sentenced to death under a charge of espionage. In fact, she had accepted a job as cleaning lady in the German Kommandantur because she worried about her 14-year-old daughter, Ninel, forcibly recruited by the Germans while she walked in the street. At the Kommandantur, Varvara met a German interpreter and had a love affair with him. This domestic story became, under the direction of regional NKVD officer Kurusenko, a large espionage network case (1943-1944). Bol'shev and Monikovskaia's mother were the head while Petrova, Alekseeva and Ninel were mere agents. When the case was revised in 1960, all the witnesses refuted the latter interpretation and told the story of a worried mother. ${ }^{72}$ The same can be said of Zolotov's case. Arrested on January 5, 1942, he was interrogated twice before being indicted three days later. No witness testimony appears in the record. The charges raised against him consisted in his having been a starosta (a sort of rural mayor) and a storeman under German occupation for two months. The expeditiousness of the inquiry can explain the error in the qualification of the crime: these activities should have been qualified under Article 58-3 rather than 58-1a. But neither the prosecutor nor the tribunal corrected the error. At that time, such errors were quite frequent: a fitfth of our cases were requalified between the inquiry and the sentence. About 20 starosta were harshly repressed - though not all were sentenced to death - even when no serious charges, such as proven denunciation of cruelty against their fellow villagers, could be raised against them. NKVD organs seem to have prosecuted such collaborators on the sole basis of neighbors' testimonies. No evidence of heavy consequences, such as the death of a Soviet citizen, is ever brought forward in the files. Their rehabilitation in the 1990s is generally based on lack of proofs, the absence of crime in the crimes. Police and justice seem to have understood high orders of "total fight against German agents" as a signal for radical cleansing of counterrevolutionary elements. Repressive actors had probably kept the 1937 order against old class enemies (kulaks, priests, nationalists) in mind. Indeed, another striking feature of our records is the large number of dubious biographies. Seven condemned persons had alien social origins: sons or daughters of merchants, kulaks, and so on. Eleven had earlier been repressed by Soviet justice. Six older men had experienced German or Austrian captivity during World War I. The facts here join the official discourse about hidden enemies of the Soviet regime taking off their masks upon the arrival of the Germans..$^{73}$ One may assume that some of these men and women actually felt

72. TKhDNI, f. 7849, d. 17535s, vol. 4.

73. See, amidst dozens of articles: I. Lysenko, "Chto tvoritsia $v$ zakhvachennykh raionakh Ukrainy," [What is happening on the captured regions of the Ukraine]Krasnaia Zvezd, (September 5, 1941): 3; P. Korzinkin, "Podvig smolenskogo krest'ianina" [The feat of a Smolensk peasant] Krasnaia Zvezda (October 5, 1941): 4; P. Beliavskii, "Predatel'," [A traitor] Izvestiia (October 24, 1941): 2; "Prisluzhniki palachei," [Servants of the executioners] Izvestiia, (January 9, 1942): 3; "V voennom tribunale: Predatelia - k rasstrelu," [In a military tribunal: traitor must be shot] Izvestiia (January 14, 1942): 3. 
resentment against Soviet power, which made collaboration easier. But on the other hand, NKVD agents might have followed their prejudice to become convinced of these people's disloyalty and aggravate the charges against them.

Anyway, thanks to several "Explanations" provided by the General Prosecutor's office and reports from the presidents of military tribunals about the improper qualification of crimes by the NKVD, we found out much about numerous "errors" in the judicial practice of retribution against collaborators. These flaws led central powers to attempt to clarify the legal basis. A divergence arose between, on one side, Prosecutor's and Commissar of Justice's viewpoints, and, on the other side, the Head of the NKVD's viewpoint. For example, the USSR Prosecutor's Order, dated May 15, 1942, "On qualification of the crimes of people who joined the enemy's administration in temporarily occupied districts" called for severe retribution (58-1a) against civilians sold out to the enemy forces, helping them collect useful things for the army or convicted of denunciation of partisans, members of the party or the komsomol. Indeed, as we saw, the percentage of incorrect qualification was high (20\% of our sample for 1942). At the same time, Bochkov condemned the use of this article against administrative employees of the occupying forces who secretly helped the Soviet side in some way or another. He also condemned prosecution of people carrying on their previous activities under occupation without any intention of betraying the country. Here, the prosecutor obeyed the principle of "no intention, no crime." He ordered to stop ill-founded prosecutions against suspected collaborators. That is another basic principle: "no proof, no crime." Lastly, he urged acceptance of spontaneous surrender to the police as mitigating circumstance. ${ }^{74}$ According to Epifanov, the Prokuratura's control over inquiries was strengthened at the same period and in June 1942, the Direction of the Military Tribunals issued another directive on the same topic. ${ }^{75} \mathrm{We}$ must assume that, as the time had not come yet to end the repressive campaign, these texts only tried to stop total arbitrary rule in the NKVD's activity and promote a more balanced practice in the retribution against collaboration. This thesis finds a confirmation of sorts in the joint decision of the chief of military tribunals and the head of the military prosecutor's office of July 16,1942. They forbade transmission to the tribunals of inconsistent cases to be judged in absentia and demanded that death penalties be ratified by the front military tribunal or the military council. In March 1943, the military prosecutor condemned the following infractions: arrests without a prosecutor's ratification, returns of cases to the stage of inquiry because of incomplete records due to the orientation of the questioning towards the version given in the suspect's confession. For example, in Stavropol territory, NKVD officers contented themselves with questionings of the suspect and certificates about his starosta activity. In Voronezh province, more than a fourth of the cases were returned by the tribunals for further inquiry... ${ }^{76}$.

74. Sbornik zakonodatel'nykh i normativnykh aktov o repressiiakh..., p. 39-41.

75. Epifanov, Otvetstvennost' za voennye prestupleniia..., p. 88.

76. Ibid., p. 196, 119. 
Investigation reports and trial minutes reveal shy attempts on the field to introduce levels of collaboration in the judicial system. According to our sample, in the stormy repression of the winter and spring of 1942, only $25 \%$ of the collaborators escaped the death penalty. The figure is low, but we must keep in mind the context of war and the fear of a return of the Germans in temporarily freed territory. In the Rzhev district, for instance, the Germans retreated three times and some collaborators served twice under them. This fact does not excuse or justify arbitrary repression. But it helps us understand the severity of sentences in an area where mass murders were quite rare. ${ }^{77}$ Proximity to the places where the crimes were committed might also explain the peculiar harshness of field organs. The latter never took mitigating circumstances into account. Subsequent revisions reveal a deep ignorance of facts in the suspect's defense. In Terent'eva's case, for instance, the intervention of a lawyer in April 1945 caught the attention of the Military College of the Supreme Court... in April 1947!78 The lawyer showed the flimsiness of the charge of counterrevolutionary agitation and put forward the testimony of a Jewish man whom Terent'eva hid in her cellar during the occupation of Kalinin. Instead of ten years of labor camp followed by five years of deprivation of rights, she received five years and was released straight away. For the engineer Dobrynin, also sentenced to ten years in December 1943, the military college assessed that his assistance to the Germans was not demonstrated and that the work he achieved during occupation also served the Soviet population. ${ }^{79}$ This decision is all the more surprising as an appeal from his daughter had been rejected by the prosecutor's assistant in September 1942.

More generally, time and the level of the judicial organ seem to play in favor of the repressed. The following tables, based on the revision practice of the Supreme Court and its military college, show that these higher authorities demanded concrete facts to ratify death penalties or lengthy camp terms.

For both articles 58-1a and 58-3, the number of closings of cases or returns to the preliminary inquiry far exceeds the number of sentences rendered more severe The ten death penalties in first instance became two for the Military College and just one for the plenum of the Supreme Court. The part of closed cases is appalling: nearly a fifth. That way, the revision practice shows that an intervention of the Supreme Court usually played in favor of the convicted. ${ }^{80}$ For example, in the

77. Except in one place near the southwestern border of the region (Sychevka), we found no mention of massacres, probably because of the absence of large Jewish communities. Nevertheless, there were collective slaughters of civilians and individual arbitrary executions, especially of people suspected of providing assistance to the partisans. Instances of pure cruelty are numerous, too.

78. TKhDNI f. 7849, d. 12439s, 1.75 and 88-88ob.

79. TKhDNI, f. 7848, d. 11480,1.31-31ob.

80. According to Petukhov and Serov, the Military College "radically corrected the work of a great number of military tribunals in the army and the rear." Our observations seem to be confirmed by the overall study of the Military College's revision practice. Nikolai Petukhov, M. Serov, "Voennaia kollegiia verkhovnogo suda SSSR vo vremia voiny," [Military panel of the Supreme Court of the USSR during the war] Zakonnost', 2 (1995): 24-27. 
Comparison of judgments in first, second and final instances, 1943-1944

\begin{tabular}{|c|c|c|c|c|}
\hline & Type of judgments & $\begin{array}{l}\text { Military } \\
\text { tribunal } \\
\text { (first } \\
\text { instance) }\end{array}$ & $\begin{array}{l}\text { Military College } \\
\text { of the USSR } \\
\text { Supreme Court }\end{array}$ & $\begin{array}{l}\text { Plenum } \\
\text { of the USSR } \\
\text { Supreme } \\
\text { Court }\end{array}$ \\
\hline \multirow{7}{*}{ 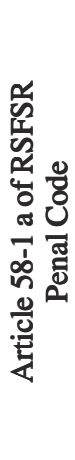 } & Acquittal & & & \\
\hline & Term in a labour-corrective camp & 13 & 8 & 5 \\
\hline & Death penalty & 10 & 2 & 1 \\
\hline & $\begin{array}{l}\text { Return to instruction or court } \\
\text { because of a judgment too "liberal" }\end{array}$ & & 1 & \\
\hline & $\begin{array}{l}\text { Return to instruction or court } \\
\text { because of a judgment too harsch }\end{array}$ & & 1 & \\
\hline & $\begin{array}{l}\text { Return to instruction or court } \\
\text { because of onconvincing evidence }\end{array}$ & & 7 & 13 \\
\hline & Closing of the case & & 4 & 4 \\
\hline \multirow{5}{*}{ 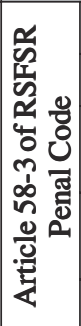 } & Acquittal & 2 & & 1 \\
\hline & Term in a labour-corrective camp & 2 & 1 & \\
\hline & $\begin{array}{l}\text { Return to instruction or court } \\
\text { because of a judgment too "liberal" }\end{array}$ & & 1 & \\
\hline & $\begin{array}{l}\text { Return to instruction or court } \\
\text { because of onconvincing evidence }\end{array}$ & & 1 & 2 \\
\hline & Closing of the case & & 1 & 1 \\
\hline
\end{tabular}

GARF, f. 9474, inv. 1, files 135-149.

Smitchenko case, the Supreme Court decided to close the case because the defendant's guilt was not proven and could not be. Indeed, Petr Smitchenko was sentenced to seven years of labor camp and three years of deprivation of rights by the military tribunal of NKVD troops in the North Caucasus (February 25, 1942). He was accused of taking part in the restoration of the mill in the occupied village of Siniavskoe and then working there with a German arm-band for 23 days. The plenum of the Supreme Court cancelled the sentence because interrogation of witnesses did not demonstrate Smitchenko's voluntary enlisting. It closed the case because the village was occupied again, and it was impossible to resume the inquiry. ${ }^{81}$ Another case reveals the professional attitude of the Supreme Court towards these cases, compared with both the first instance tribunals and the Military College. Its April 1, 1943 resolution in the Rafailov case rejected the decisions of both. The military tribunal of the Samarkand garrison sentenced Mikhail Rafailov to death on December 9, 1942 under Article 58-1a and 58-10. The Military College cancelled this sentence and closed the case two months later. USSR Prosecutor 
Bochkov turned to the plenum and asked for a new inquiry. Rafailov was accused of being an interpreter for the Germans during their presence in Rostov on Don in November 1941. Moreover, he accepted work as a building manager and, in this function, forced the inhabitants to work for the Germans, threatening them with denunciation, expelled a Soviet woman from her flat in order to give it to the Germans, and spread anti-Soviet propaganda in the building. The Military College concluded that the NKVD had not cast light on several major circumstances. Notably, it did not interrogate witnesses in Rafailov's defense. The plenum agreed with the Military College but, instead of closing the case, ordered a new investigation as Rostov had just been liberated. ${ }^{82}$ Our small sample of revision decisions confirms the spirit of the preliminary inquiries we mentioned above. Indeed, a report on the military tribunals' activity in 1942 noted that $38 \%$ of the 15,743 cases investigated were incorrectly qualified during investigation. Such errors brought discredit to the meaning of the retribution. For instance, choosing Article 58-3 instead of Article 58-1a did not allow to display enough harshness in serious cases (the author pointed here to the repression of the families of a condemned person under Article 58-1) ${ }^{83}$ Conversely, excessive use of Article 581a could easily erase important differences between levels of treason. High judicial organs seem here to attach great importance to the educative purpose of justice. That fact illustrates a history of Soviet judicial practice which dates as far back as the 1920s: lower courts were accused to mete out excessively harsh sentences because, politically, that was the safest way to proceed for grassroots judges. A high percentage of sentences were overruled: on the eve of the war appeal courts reversed between $20 \%$ and $40 \%$ of sentences in the political cases that reached them. ${ }^{84}$

The first year of practice in judicial retribution against collaboration shows several trends. First, on the local level, NKVD investigators conformed to their habit of partial inquiry at the expense of the suspect, whose confession often constituted the main evidence. Nightly questioning, brutalities easily overcame defendants' resistance all the more so because they were not assisted by a lawyer, and the prosecutor's control was very light. Taking the appeals to severity literally, NKVD organs and military tribunals heavily charged petty collaborators in the context of a new repressive campaign. But obviously, the high judicial authorities held a stricter line of observance of the law than the courts. That way, later revisions smoothed expeditious sentences and attempted to give meaning to the repression by introducing levels of guilt and punishment. The decree of April, 1943 went further in that direction.

82. GARF, f. 9474 , op. 1, d. 138, 1.24-24ob.

83. Epifanov, Otvetstvennost' za voennye prestupleniia..., 73-74.

84. Rittersporn, "Extra-Judicial Repression and the Courts: Their Relationship in the 1930s...," 216-217. 


\section{3: The turning point}

The year 1943 is a turning point in several ways. First, the victory in Stalingrad seriously undermined the prospect of a German victory. Support to the Germans dwindled and passages to the partisans' side critically increased. On the international scene, the USSR began claiming for the opening of a second front in Europe, with greater confidence as the recently created Extraordinary State Commission for Ascertaining and Investigating Crimes Perpetrated by the German-Fascist Invaders and their Accomplices (ChGK) began providing solid evidence of the huge losses suffered by the country. ${ }^{85}$ Finally, the Soviet Union attached more and more importance to the question of war criminals' punishment. Moscow wanted to send a strong signal both to its suffering population and to perpetrators. The former must understand that Soviet power was firmly back in a larger and larger territory and resolved to do justice to the victims; the latter were threatened with harsh retribution for their past and future crimes. A significant coincidence adds other stakes to the devising of the decree: an April 15, 1943 order summoned ChGK delegates to hurry along the work in progress, ${ }^{86}$ and SMERSh the Soviet counterintelligence body - was created on the same date as the decree. In fact the decree appeared to be a good juridical framework for SMERSh and it was widely used in SMERSh documents. The diversity of the stakes introduced difficulty in the already intricate issue of retribution against collaborators.

The Soviet Union can pretend to one of the first places in the reflection on the penal responsibility of war criminals. It raised the problem as early as 1941, and People's Commissar of Foreign Affairs Viacheslav Molotov issued several "Notes" on the topic in 1941 and 1942. Indeed, there was no judicial practice of war crimes punishment before World War II. The existing texts, dating from the end of the nineteenth century and World War I (Versailles Treaty, Articles 227-231), were not appropriate to qualify the atrocities perpetrated by the Axis troops. They failed to create the means of punishing high standing criminals. In his answer to a Note dated January 1942 addressed to Stalin by the exiled representatives of occupied countries, the president of the State Defense Committee made public a declaration, on October 14, 1942: "On the liability of the Hitlerite invaders and their accomplices for the

85. On ChGK, see Epifanov, Otvetstvennost' gitlerovskikh voennykh prestupnikov..., 81 ff.; Nathalie Moine, "La commission d'enquête soviétique sur les crimes de guerre nazis: entre reconquête du territoire, écriture du récit de la guerre et usages justiciers," Le Mouvement social, 1, 222 (2008): 81-109; Marina Sorokina, "People and Procedures: Toward a History of the Investigation of Nazi Crimes in the USSR," Kritika: Explorations in Russian and Eurasian History, 6, 4 (2005): 797-831; K. Feferman, "Soviet investigation of Nazi crimes in the USSR: documenting the Holocaust," Journal of Genocide Research, 5, 4 (December 2003): 587-602.

86. Kalinin Regional Commission was founded by the "Soobshchenie Kalininskoi Oblastnoi Komissii po ustanovleniiu i rassledovaniiu zlodeianii, sovershennykh na territorii oblasti," [Information of the Kalinin regional commission on investigation of the murderous deeds committed on territory of the region] dated April 9, 1943 (GATO R-1925, op. 1, d. 4,1. 12). But in fact, "spontaneous" local commissions began to register citizens' declarations immediately after the liberation of the various places (see GATO R-1928, op. 1, d. 2). 
atrocities committed in occupied Europe." 87 The Soviet government pledged to hand the guilty over to the law and to implement the sentences for high standing officials as for basic soldiers. At the same time, it suggested the creation of an international court of justice for the main criminals. The two other Great Powers, Britain and the USA, agreed to disapprove in a most official way the barbarous acts committed in the occupied countries: Roosevelt (at that time not involved in the war) and Churchill made respective statements on the topic as early as October 27, 1941.88 But they reluctantly touched on the concrete aspects of punishment at that stage of the war. First, they did not reach an agreement on the fate of Reich leaders: they both (the USA until 1944 and Great Britain until 1945) hesitated between the projects of summary executions and judicial prosecutions of Hitlerite leaders. Second, unlike the USSR, these countries did not experience occupation on their soil. Punishing war criminals appeared less efficient for their national mobilization than for the Soviet Union. And the effect in 1942-1943 could be the opposite: instead of scaring Axis powers, it could provoke them to retaliate against English and American POWs. ${ }^{89}$ Concerning subordinate war criminals, the Great Three agreed on their prosecutions in the country where they committed their crimes. However, Churchill and Roosevelt opposed precocious trials: they feared reprisals against their nationals detained by Japan and Germany and thought that a war context could not guarantee the conditions for fair trials. Meanwhile, the Soviet Union was trying to promote its view and was devising criminal principles of retribution which fitted well with the 1930s' frames of a fascist conspiracy.

As early as the winter of 1942, Lozovskii, head of the Soviet Information Bureau, was in touch with American editors about a project for a documentary book on Nazi exactions on Soviet soil, most probably to inform the American public. ${ }^{90}$ Lozovskii was also one of the first officials who proposed a project for a Commission of evaluation of Nazi crimes on Soviet territory (December 1941). In the spring of 1942, the Central Committee Direction of Propaganda worked on that idea, and the ChGK was founded in November. According to M. Sorokina, the ChGK was thought from the very start as a means to promote Soviet claims in the international arena. Its materials were widely used in Nuremberg and in the trials of the 1960's when the Soviet Union accused the USA and Western Germany of protecting Nazi henchmen. ${ }^{91}$

87. Evoked by Epifanov, Otvetstvennost' gitlerovskikh voennykh prestupnikov..., 12. The text of the Declaration was published in Pravda (October 15, 1942).

88. Ginsburgs, Moscow's Road to Nuremberg, 25.

89. Kochavi, Prelude to Nuremberg, 27-61.

90. RGASPI, f. 17, op. 125, d. 79,1.1,7.

91. Sorokina, "People and Procedures." For Soviet denunciations of Western inaction in the 1960s, see I. Lediakh, F.M. Reshetnikov, "Kazhdyi natsistskii prestupnik dolzhen ponesti nakazanie" [Every Nazi criminal must be punished] Sovetskoe Gosudarstvo i Pravo, 2 (1965): 24 33; R. Rudenko, "Gitlerovskie palachi ne dolzhny uiti ot vozmezdiia," [Hitlerite executioners must not evade penalty] Sotsialisticheskaia Zakonnost', 3 (1965): 2-8; L.N.Smirnov, "Niurnbergskii protsess," [Nurenberg Trial] Sovetskoe Gosudarstvo i Pravo, 2 (1966): 3-11. 
From that time onwards, the penal definition of war crime and recording of the occupant's atrocities were tightly connected. In that respect, the Soviet side was not deprived of ulterior material motives: during the war, British and American material help appeared more than welcome; after the war, a precise bill would be presented to Axis countries. Eventually, the Moscow Conference ended up with an Ally joint declaration, on October 30, 1943: "Concerning Responsibilty of Hitlerites for Committed Atrocities" signed by Stalin, Churchill and Roosevelt. It settled the principle of local prosecution of each soldier whose guilt was proven.

However, Soviet penal legislation did not wait so long to mark out the infamy of those crimes. The country already had more than a year of cleansing experience which promised to be significantly improved thanks to ChGK-collected information. On the judicial aspect, a lesson might have been drawn from the massive repressions of 1942, which did not exploit enough media coverage. The famous Soviet jurist N.N. Polianskii proposed a February project ("On the organization of penal prosecutions of crimes linked with the war") to the ChGK, recommending, besides the international trials of leading war criminals, the application of Soviet war laws to subsidiary war criminals. According to Epifanov, most jurists believed that the prewar Penal Code was unsuited to the Nazis' massive and organized crimes: they advocated for a hardening of norms.92 The Krasnodar trial of 1943 helps us better understand the evolution of Soviet legal thought on the matter. Even though 11 Soviet collaborators were sentenced to death for mass murder of civilians, the trial actually prosecuted the German ruling elite in absentia. The real responsibility for the crimes committed in Krasnodar territory was ascribed to German commanders: the commander of the 17th Army, the head of Krasnodar Gestapo and 14 other Gestapo officials. The collaborators were mere executants of Hitler's vast criminal project.93 We find here an argument very similar to that of the 1937-1938 political trials. Soviet inner enemies constitute a fifth column serving foreign fascist and capitalist states. This does not diminish the seriousness of Soviet traitors' acts: on the contrary, in such a light they appear as the worst counterrevolutionary enemies, who lend a hand to foreign aggressors in order to overthrow the regime. Francine Hirsch underlined the relation between Vyshinskii's ideas, expressed in 1937-1938 in his indictments against the defendants of the Moscow trials, and the theory devised by his subordinate at MGU, Aron Trainin, about a Nazi conspiracy against peace. ${ }^{94}$ Vyshinskii signed impassioned forewords to Trainin's 1937 and 1944 works, The Defense of Peace and Criminal Law and The Criminal Responsibility of the Hitlerites. In fact, Vyshinskii himself had ordered Trainin to think and write on these topics. Trainin's works are fascinating because they manage to develop international law while

92. See I.P. Trainin, "Otvetstvennost' gitlerovtsev za zlodeianiia," [Responsibility of the hitlerites for their murderous deeds] Vestnik Akademii Nauk, 1-2 (1943): 47.

93. Kochavi, Prelude to Nuremberg, 65.

94. F. Hirsch, "The Soviets at Nuremberg: International Law, Propaganda, and the Making of the Postwar Order": 701-731. 
providing arguments in favor of Soviet discourse about a wide conspiracy involving inner counterrevolutionary elements and foreign enemies of peace.

The April 1943 Decree on the punishment of Hitlerite war criminals responsible for murders and torture of Soviet civilians and POWs must be analyzed in this context. In their thorough study of the genesis of the decree, Hilger, Petrov and Wagenlehner revealed that Stalin himself ordered four high officials to work on a draft at the beginning of $1943,{ }^{95}$ Malenkov, secretary of the party's Central Committee and member of the GKO, Goliakov, chairman of the USSR Supreme Court, Gorkin, secretary of the Presidium of the Supreme Soviet, and Bochkov. We must note that as it often happened under Stalin, the 1943 Decree did not found a new legal basis but substituted one to it. That Decree is in fact one in a series of similar acts adopted under Stalin before, during and after the war. They all assume an extra-ordinary character, demand harsh measures and impose severe punishment. One can mention the decrees of July 10, 1940, which introduced more severe punishment for theft, or the one of August 10, 1940 (punishment for hooliganism). Another severe Ukaz was introduced on December 26,1941 . It punished unauthorized departure from the job with sentences up to eight years in prison. The Decree of June 4, 1947 recommended up to 25 years imprisonment for theft. 96

A preliminary version of the Decree was written by Bochkov, Goliakov and Gorkin and then sent to Malenkov. Malenkov edited it and sent it to Stalin on April 9, 1943. Stalin made little correction on it and then the Decree was adopted by Politburo decision. We can thus assume that Stalin and his close associates bear responsibility for it.

Why was this new text necessary? According to the 1926 Penal Code, foreign criminals underwent Soviet penalties if they committed their crimes in the USSR. In our view, the decree aimed at distinguishing Nazi crimes from ordinary penal and war crimes. More precisely, its purpose was to confirm in Soviet law Trainin's theory of a Hitlerite large-scale criminal project. Indeed, the decree focused on murder and violence against the defenseless Soviet people: the crime denounced here is mass extermination planned by a political leadership, and not scattered murders. For ideological reasons, the decree does not evoke racist extermination. But it underlines that Hitlerite criminals killed children, women and old people outside military purposes (see appendix). It heavily insists on the large amount of these crimes ("numerous cases", "several thousands of victims") and draws out an antithesis between bloody monsters, barbarian beings (zveri) and poor, defenseless people (children, old people and POWs). Last, the vocabulary is revealing:

95. Andreas Hilger, Nikita Petrov, Günther Wagenlehner, "Der 'Ukaz 43': Entstehung und Problematik des Dekrets des Präsidiums des Obersten Sowjets vom 19. April 1943," in A. Hilger, ed., Sowjetische Militärtribunale. 1, Die Verurteilung deutscher Kriegsgefangener 1941-1945 (Köln: Böhlau, Schriften des Hannah-Arendt-Instituts für Totalitarismusforschung (17), 2001), 180-185.

96. Istoriia stalinskogo Gulaga [History of the stalinist GULAG], vol. 1, Massovye repressii v SSSR [Mass repressions in the USSR] (M.: ROSSPEN, 2004). 
"savagely" (zverski), bloody reprisals (krovavye raspravy), "the most shameful and serious crimes, the vilest exactions" (samye pozornye i tiazhkie prestupleniia, samye gnusnye zlodeianiia). Stressing the unity of all these acts, the decree includes Soviet collaborators in the Hitlerite clique.

The penalties are revealing too. Concerning Axis troops, the decree imagined a way of inflicting infamous death - hanging, in order to imitate Nazi practices against partisans on occupied territories. Furthermore, and it was a very important move - for thousands of Soviet people it introduced hard labor (katorga, in reference to an old tsarist punishment), which, in fact, meant slow death in a camp. Both penalties constitute a move backwards. Hanging was an archaic way of inflicting death, whose use stopped when shooting appeared as a more convenient and "civilized" way of killing. Besides imitating Nazi punishment of Soviet patriots, it presented the advantage of humiliating the condemned. Moreover, the decree specified that the bodies should be exposed on the gallows for several days. The execution of Nazi war criminals had to be spectacular and awe-inspiring; the numerous documentary films on those executions are eloquent.97 As for the collaborators, katorga meant a regression to tsarist times. It meant that these traitors were not considered worthy of re-education. Soviet corrective penal law vaunted its essential difference from bourgeois cruel and useless punishment. For the creators of labor camps, nearly any criminal could be re-educated through useful work. ${ }^{98}$ These "humane" dispositions of Soviet penal law could not be applied to the worst collaborators. We did not find documents about the devising of these penalties dated 1943. But the Russian State Archive houses two files containing reflections on katorga: the first is dated 1945, the second 1951. However, we suspect that the authors of the 1943 Decree had read some of the notes on tsarist katorga prepared by the Gulag administration. Indeed, the project of the Decree states in paragraph 2: "Helpers found guilty of assistance to the villains in their atrocities and violence against the civil population and captured Red Army soldiers must undergo corporal punishment - birching from 50 to 100 lashes - if by law, the nature of their actions does not lead to imprisonment." 99 It is not clear who changed and rewrote the paragraph in favor of the katorga penalty and not the birching. But we can

97. RGAKFD (Rossiiskii Gosudarstvennyi Arkhiv Kinofotodokumentov - Russian State Archive of cinematographic and photographic documents), no. 5056 and 8700 (Krasnodar trial), 5070 and 6065 (Kharkov trial), 5399 and 8450 (Smolensk trial), 6016, 6288, 6401-1, 6524 and 8591 (Kiev trial), 8869-4,9134-2, 10795, 22012, etc.

98. A.A. Gertsenzon, ed., Voprosy ispravitel'no-trudovogo prava. Sbornik statei [Issues of the labour-correctional legislation. Collection of articles] (M.: Nauchno-issledovatelskii otdel GUITK MVD SSSR, 1957); M.D. Shargorodskii, Nakazanie po sovetskomu ugolovnomu pravu [Punishment under the Soviet penalty law] (M.: Gosudarstvennoe Izdatel'stvo iuridicheskoi literatury, 1958); E.G. Shirvindt, B.S. Utevskii, Sovetskoe ispravitel'notrudovoe pravo [The Soviet labour correctional law] (M.: Izdatel'stvo Narodnogo komissariata vnutrennykh del RSFSR, 1931).

99. AP RF, f. 3, op. 50, d. 540,1. 124-126. 
determine that the idea of birching directly came from a note on tsarist katorga. 100 In opposition to the katorga penalty, there was no hope for the convicted to survive birching from 50 to 100 lashes.

Thus, the decree possessed paramount political significance. However, it did not really help clear up judicial confusion or root nuances in practice. As we said, the decree essentially established the idea of a Nazi criminal project. The vocabulary is more denunciatory than legal. The concrete field of application (the nature of the crimes covered by the new text) is not clearly fixed. Operative directives had to be addressed to the NKVD and judicial organs to describe how to proceed. On May 18, 1943, the head of the Direction of Military Tribunals sent an instruction to his subordinates. The text explained that the decree had a retroactive effect and, as it gave both formal and concrete definitions of the crime, judicial organs had to determine whether the described consequences (murder, acts of violence) were recognized in the case. If they were not, the crimes came under ordinary penal law. Referring cases deprived of the concrete signs mentioned in the decree to the field military courts (special tribunals created by the decree) was a gross infraction. Then the instruction listed various rules of referring to field military courts, rules about the publicity to give to those trials, etc. A month later, the USSR Prosecutor addressed a directive finally describing the "consequences" necessary to use the decree: murder of civilians, acts of violence, torture and abuses on defenseless people, that is, women, children and old people, forced deportation, acts of violence on Soviet POWs. ${ }^{101}$

But soon, new problems relative to field military courts came up. These kinds of military troikas, composed of the president of the local division military court, the head of the NKVD Special Department (of the division), and the assistant of the division commander in charge of political affairs were the only jurisdictions authorized to use the decree. In a letter to the president of the Supreme Soviet Presidium in July 1943, I. Goliakov asked for his court to be given the same rights as the field military courts:

The USSR Supreme Court, as the highest organ of judicial control, examines a great number of affairs of Soviet people sentenced to death [on the basis of the Decree]. Quite often, resort to the death penalty does not appear necessary, considering the degree of activity of the offenders, but, on the other hand, the next more moderate punishment consists of 10 years of detention, which does not correspond to the committed crime. ${ }^{102}$

This request suggests that the field military courts used very harsh measures against Soviet collaborators, which led the Supreme Court to revise the sentences. Then it shows that the higher organs of justice considered the death penalty as an excessive

100. GARF, f. 9414 , op. 1, d. 76,1.137-139ob. The birching from 50 to 100 lashes is evoked on 1. 138ob: according to the author of the note, that punishment was introduced by the circular "On the rules of detention in katorga," 1907.

101. Epifanov, Otvetstvennost' za voennye prestupleniia..., 52, 58-59, 84, 197-199.

102. GARF, f. 7523 , op. 65 , d. $311,1.1$. 
retribution for some cases of lesser "activity," while the detention penalty available in the prewar Penal Code (10 years) appeared too soft. Thus, the new decree filled a gap in the scale of penalties. However, it did not propose a gradation in the crimes and penalties for the various forms of petty collaboration. There was no reflection about the difference of meaning between, for example, a German soldier obeying - or not - a criminal order, a Soviet civilian who was not evacuated and faced a bitter dilemma, and a willing collaborator. The question of intention was not even raised, though it is supposed to be crucial in penal justice. Lastly, the decree was rather ambiguous in its enumeration of the atrocities it condemned. It listed general cases of violence but no precise circumstances nor the degree of implication of the defendants in the crime. This part was, consequently, left to the discretion of the NKVD and the field courts...

But the main aspect was that the decree only concerned the violent crimes of collaboration: petty economic, administrative, and usual collaboration remained in the field of Article 58 qualification. That is the reason why we assume that the decree essentially aimed at giving a spectacular and exemplary dimension to the punishments in order to provide an outlet to society's thirst for vengeful justice and demonstrate Soviet power. In addition, the condemned had to be specially stigmatized. Indeed, as early as 1942, we observe the first propagandistic exploitations of the horrible testimonies collected in freed territory which aimed at galvanizing the Soviet army and driving local inhabitants to engage in passive - or active - resistance. Regular articles in the local and national press fostered a spirit of reprisals: "Acts", (akty) about German atrocities in some village and district were very often published. On April 2, 1942, Aleksandrov, head of the Agitation and Propaganda Direction of the Central Committee, triumphantly reported to Andreev the plain success of a mission of collective farmers from freed territories sent to various places in the rear to tell their story. According to him, almost 50,000 citizens had heard these testimonies. ${ }^{103}$ As a result, local authorities registered numerous commitments to "overfulfilling" the plan and gathering clothes for the army and the freed population of the Western provinces. On May 30, 1942, Proletarskaia Pravda (Kalinin's regional newspaper) published the article "Who betrayed Liza Chaikina?", ${ }^{104}$ in which a primitive opposition was drawn between a heroic young girl and an abominable traitor to the Motherland who took off his mask during occupation. The year 1943 marks a turning point in that enterprise: up to that time, the political organs of the army and the NKVD exploited the testimonies of confused witnesses coming to them in a quest for justice. From that date onward, the existence of the ChGK allowed to systematize that action by centralizing evidence and testimonies. The information was used to mobilize the nation as well as strike the international community. The Krasnodar trial enjoyed wide coverage in Pravda (lengthy articles on each day of the trial, from the 14th to the 19th, the day following the hanging), in Proletarskaia Pravda (three long articles 
dated July 17, 18 and 20), and was quoted as an example to be used by propagandists in Pamiatka Agitatora ("the agitator's crib sheet") issued in 1943.105

Even foreign observers noticed the special attention attached to propaganda. In Krasnodar and Kharkov, where three German criminals and one Soviet collaborator were judged in December 1943, the hanging was carried out in front of more than 30,000 people and a documentary film was projected in local cinemas and even in Moscow (for the Kharkov trial). ${ }^{106}$ The films can be seen in Krasnogorsk archive (RGAKFD). Indeed, the size of the crowd is impressive, such as in Melitopol for another hanging of collaborators in 1944.107

In fact, big show trials of collaborators and war criminals were not so frequent during and after the war. The literature on the topic only points to Krasnodar, Kharkov, and the eight trials of 1945-1946.108 But Krasnogorsk's films prove that there were local public trials and shootings as soon as $1942 .{ }^{109}$ However, hangings were shown only since legal courts were authorized to precribe hangings - as we saw, the penalty was reserved to foreign war criminals. ${ }^{110}$ The films give priority to the hanging, while the trial itself is sharply summarized, which points out to the cleavage between the broad coverage given to Nazi crimes and the silence kept about the purges of collaborators as a specific issue. The rare occasions when collaborators were evoked in the press contributed to create a caricatural and oversimplified image of them. The standard representation of the Soviet collaborator is best illustrated in Pravda's description of the Krasnodar convicts: monsters who freely enrolled in German formations and took part in atrocities against civilians. This is a partial and biased portrait which focuses public attention on the worst and harshest collaborators, ignoring the thousands of petty collaborators, forced to give their last stock of potatoes to the occupant or work for

105. We thank the GATO archivist in charge of the library for her help in consulting the old issues of Proletarskaia pravda, 147, 148, 149 (1943): 2 and in showing us the brochure Sputnik Agitatora.

106. Kochavi, Prelude to Nuremberg, 65-68.

107. RGAKFD, 10795, Kazn' predatelei v Melitopole [Execution of the traitors in Melitopol], 1944, Tsentral'naia studiia dokumental'nykh fil'mov, 107, 5 m.

108. Kochavi, Prelude to Nuremberg; Ginsburgs, Moscow's Road to Nuremberg; A.V. Prusin, "Fascist Criminals to the Gallows! The Holocaust and Soviet War Crimes Trials, December 1945-February 1946," Holocaust and Genocide Studies, 17, 1 (2003): 1-30; I. Bourtman, "'Blood for Blood, Death for Death': The Soviet Military Tribunal in Krasnodar," Holocaust and Genocide Studies, 22, 2 (Fall 2008): 246-265.

109. RGAKFD, 9049, Rabota polevoi pochty $i$ sud nad predateliami [The functioning of the military post service and trial over the traitors] (1941); 6225-2, Iugo-zapadnyi front [The southwestern front] (1942).

110. RGAKFD, 8869, Otriad Fedorova [Fedorov's detachment] (1943); 6401-2, Sudebnyi protsess v Pavshine [The Trial in Pavshin] (1943); 6288, Sudebnyi protsess nad predateliami [The trial over the traitors] (1943); 8595, Bitva za Sevastopol' [Battle for Sevastopol](1943); 10795, Kazn' v Melitopole [Execution in Melitopol](1944) and the Krasnodar, Kharkov, Smolensk and Kiev trials. 
him under various threats. Actual criminals had to be sentenced, undoubtedly; but what about all the others, thereby labelled as "monsters" and "traitors?"

\section{Conclusion}

The Soviet judicial device used to retribute against collaborators strikes the Western observer by its similarity with the 1930s' procedures and principle of "campaign justice." Whereas in the rest of Europe, special laws and jurisdictions were devised to deal with that unprecedented phenomenon, the unique innovation of the Soviet Union was a decree which confirmed the Soviet theory of a great Hitlerite conspiracy involving a fifth column in the USSR. This can partly explain the absence of debate - as far as we could determine - on the nature, degree and meaning of collaboration. Labeled once and for all "treason to the Motherland," collaboration joined the list of counterrevolutionary crimes covered by Article 58 of the 1926 Penal Code.

However, the study of judicial practice reveals differences of interpretation between the organs on the field and high authorities. When the latter made a point of honor to observe the law literally and strictly hierarchize the social danger presented by various types of collaboration, the former overzealously fulfilled the 1941 appeals to severity. As a result, hundreds of petty collaborators received the death penalty just like the cruelest Nazi criminals. As in other liberated countries, the first retributions against traitors in the Soviet Union were the harshest, because the war was still going on, the organs were deprived of information and the anger was unabated.

The year 1945 witnessed a shift from wartime to peace conditions. Special military jurisdictions were abolished, and, as far as our topic is concerned, counterrevolutionary crimes came back to the jurisdiction of regional and supreme courts. In the territories freed earlier, the time of retribution gave way to the time of reconstruction. Party and state structures had already been restored, and everybody wanted to forget occupation and collaboration, and no longer have dark recollections of the war. However, collaborators sentenced in the postwar years still fell under the 1943 Decree.

But all the texts and directives reveal the Centre's strong determination to preserve the emerging myth of the war by making justice, and to keep total control over the process.

IRICE, University Paris 1

van_sin@hotmail.fr

Deutsches Historisches Institut Moskau - Moscou

Sergey.kudryashov@dhi-moskau.org 